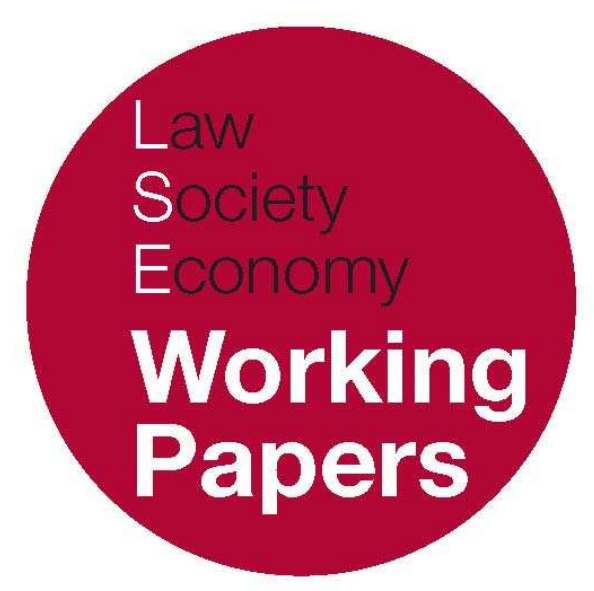

\title{
The New Substantive Test in the EC Merger Regulation - Bridging the Gap Between Economics and Law?
}

\author{
Giorgio Monti \\ LSE Law, Society and Economy Working Papers 10/2008 \\ London School of Economics and Political Science \\ Law Department
}

\begin{abstract}
This paper can be downloaded without charge from LSE Law, Society and Economy Working Papers at: www.lse.ac.uk/collections/law/wps/wps.htm and the Social Sciences Research Network electronic library at: http://ssrn.com/abstract=1153661.

(C) Giorgio Monti. Users may download and/or print one copy to facilitate their private study or for non-commercial research. Users may not engage in further distribution of this material or use it for any profit-making activities or any other form of commercial gain.
\end{abstract}




\title{
The New Substantive Test in the EC Merger Regulation Bridging the Gap Between Economics and Law?
}

\author{
Giorgio Monti ${ }^{*}$
}

\begin{abstract}
The 2004 EC Merger Regulation (ECMR) adopted the substantial impediment of effective competition test, and abandoned the earlier standard that required proof of dominance as a necessary element to intervene in a merger. It is said that this reform was necessary because the dominance test failed to catch unilateral effects absent dominance, so there was a 'gap' in the ECMR. This paper argues that the decision to amend the ECMR was unnecessary. From an economic perspective because the dominance standard was sufficiently flexible to address all anticompetitive mergers. Economists' concerns about merger control (in both the US and EC) was that authorities focused on a structural assessment premised upon market definition and market concentration and failed to give sufficient attention to other means to test for anticompetitive effects in a more direct manner. Economists' support for the new test is that it would place a focus on these other methods for identifying anticompetitive effects. From a legal perspective, it seems that the major motivation for reform was to divorce merger control from the abuse of dominance doctrine in Article 82, so that the two legal provisions would develop independently, the latter only applicable to manifestations of significant market power. Accordingly the view that there was a 'gap' in the dominance test is inaccurate, and lawyers and economists supported the reform for different reasons. This misunderstanding might explain why the Horizontal Merger Guidelines designed to indicate how the new standard applies are insufficiently precise. In an endeavour to offer some precision, the paper reviews a number of decisions and suggests that the Commission applies four distinct theories of harm, but the first major decision applying the new standard is worrying because the Commission appears to regulate the market rather than remove an impediment of competition caused by the merger, with the risk that the new standard is so loose that it allows the Commission to address questions of industrial policy through the ECMR.
\end{abstract}

\footnotetext{
* Law Department, London School of Economics. This paper was presented at two lunchtime seminars: at the Centre for European legal Studies at the University of Cambridge on 14 November 2007 at the Law and Economics working group at the LSE on 24 January 2008. Lively discussions ensued after each, and helped in sharpening this article. Thanks also to Julia Black for comments on an earlier version. Any errors remain mine alone.
} 


\section{INTRODUCTION}

In the last twenty years, the application of EC competition law by the Commission has been increasingly informed by economics. ${ }^{1}$ In the field of merger control it has operated an economically enlightened regime as a whole, however its policy on conglomerate mergers and ambiguity over the role of efficiencies have received adverse comment. ${ }^{2}$ Several defeats in the Court of First Instance suggested poor handling of economic evidence in the merger review process. ${ }^{3}$ In response to these events the Commission made some alterations to its merger procedures to avoid future errors (e.g. restructuring the Merger Task Force, creating the post of Chief Economist with a team of economists, instituting a devil's advocate panel to review merger decisions, loosening the strict timetable for review in complex cases), ${ }^{4}$ announced an intention to be more open to efficiency considerations, ${ }^{5}$ and drafted guidelines on vertical and conglomerate mergers to steer its enforcement policy towards a less aggressive stance. ${ }^{6}$ However, the most significant reform that resulted from the review of the EC Merger Regulation (ECMR) that took place between 2001 and 2004 was a change in the substantive test for analysing mergers, and is the focus of this essay. ${ }^{7}$ Unlike the reforms noted above, it did not result from any significant criticism of the merger regime, so the need for a new test and its possible impact are uncertain and worth exploring, especially in light of some experience with the operation of the new ECMR.

As originally drafted the ECMR prohibited a merger 'which creates or strengthens a dominant position as a result of which effective competition would be significantly impeded in the common market or a substantial part of it.' ${ }^{8}$ In the

\footnotetext{
${ }^{1}$ For a good overview see D. Neven, 'Competition economics and antitrust in Europe' (2006) Economic Policy 741. For the Commission's views see M. Monti, 'European Competition for the $21^{\text {st }}$ Century' 2001 Fordham Corporate Law Institute (B. Hawk ed., 2002) 257.

2 D. E. Patterson and C. Shapiro, 'Transatlantic Divergence in GE/Honeywell: Causes and Lessons' (2001) 16 Antitrust 18.

3 Case T-342/99 Airtours plc v Commission [2002] ECR II-2585; Case T-310/01 Schneider Electric SA v Commission [2002] ECR II-4071; Case T-5/02 Tetra Laval BV v Commission [2002] ECR II-4381 (Art. 8(3) prohibition); Case T-80/02 Tetra Laval BV v Commission [2002] ECR II -4519 (Art. (8(4) divestiture decision); Case T-251/00 Lagardère SCA and Canal + v Commission [2002] ECR II-4825. For comment on the legal implications see B. Vesterdorf, 'Standard of Proof in Merger Cases: Reflections in the Light of Recent Case law of the Community Courts' (2005) European Competition Journal 3.

${ }^{4}$ Press Release 'Commission adopts comprehensive reform of EU merger control' (IP/02/1856 11 December 2002).

5 Recital 29, Regulation 139/2004 on the control of concentrations between undertakings [2004] OJ L24/1. For discussion, see G. Monti, 'Merger Defences' in G. Amato and C-D Ehlermann (eds), EC Competition Law - A Critical Assessment (Oxford: Hart, 2007).

${ }^{6}$ EC Commission Guidelines on the assessment of non-horizontal mergers under the Council Regulation on the control of concentrations between undertakings (28 November 2007) (available at http://ec.europa.eu/comm/competition/mergers/legislation/legislation.html).

7 The process began with the Green Paper on the Review of Council Regulation (EEC) No 4064/89 COM (2001) 745 final, when the Commission asked if the dominance test should be replaced.

8 Article 2(3) Council Regulation (EEC) No 4064/89 of 21 December 1989 on the control of concentrations between undertakings (1989) OJ L395/13 (this was amended in 1997, a consolidated version is available at http://ec.europa.eu/comm/competition/mergers/legislation/regulation/ consolidated/en.pdf).
} 
jargon this was known as the 'dominance test.' While the Court insisted that the ECMR embodied a two stage test: (i) creation or strengthening of dominance; (ii) anticompetitive effects resulting from the creation or strengthening of dominance, ${ }^{9}$ in practice proof of dominance sufficed unless the merger was de minimis (e.g. a dominant firm acquiring a very small entity so that there is only a very small increase in dominance), or potentially a merger where efficiencies outweighed the adverse effects, or in cases where there was no causal link between the creation of a merger and the harm to competition. ${ }^{10}$ In short under the old test, proof of dominance was necessary and usually sufficient to declare a merger incompatible.

During the review of the ECMR, economists and lawyers debated whether the dominance test was sufficiently supple to apply to unilateral effects in oligopoly markets. ${ }^{11}$ Two cases brought this issue to the fore: in Heinz/Beech-Nut a merger of the number two and three manufacturers of baby foods (with market shares of 17 and 15 per cent respectively) was blocked and one of the Federal Trade Commission's rationales for this decision was that because the market leader, Gerber (with a 65 per cent market share), held an unassailable position, the merged entity would have had little incentive to compete aggressively and prices of the merged entity's goods would rise. In Volvo/Scania the EC Commission blocked a merger that would have created a dominant manufacturer of heavy goods vehicles in several Member States. ${ }^{12}$ However, an economic study carried out on behalf of the Commission had also predicted that the merged entity would have increased prices in markets where it was not going to be the market leader. ${ }^{13}$ These two cases gave rise to the following questions: if the merged entity is not the biggest player on the market but it is able to raise price or restrict output unilaterally, how can we block these mergers with the 'dominance' test? Should the

\footnotetext{
${ }^{9}$ E.g. Case T-87/05 EDP v. Commission [2005] ECR II-3745, paras 45-49.

${ }^{10}$ In this instance the Commission has sometimes applied a causation standard, and sometimes relied on the failing firm defence. For criticism, see A. Bavasso and A. Lindsay 'Causation in EC Merger Control' (2007) 3(2) Journal of Competition Law and Economics 181.

11 The literature includes: N. Horner, 'Unilateral Effects and the EC Merger Regulation - How The Commission Had its Cake and Ate it Too' [2006] 2(1) Hanse Law Review 23, S. Baxter and F. Dethmers, 'Unilateral Effects Under the European Merger Regulation: How Big is the Gap?' [2005] ECLR 380; S. Volcker, 'Mind the Gap: Unilateral Effects Analysis Arrives in EC Merger Control' [2004] ECLR 395; CD. Ehlermann, S. Volcker and G.A. Gutermuth, 'Unilateral Effects: The Enforcement Gap under the old ECMR' (2005) 28(2) World Competition 193; U. Boge and E. Muller, 'From the Market Dominance Test to the SLC Test' [2002] ECLR 495; L. Coppi and M. Walker, 'Substantial Convergence or Parallel Paths? Similarities and differences in the economics of horizontal mergers in US and EU competition law' [2004] Antitrust Bulletin 101; J. Fingleton, 'Does Collective Dominance Provide Suitable Housing for all anticompetitive oligopolistic mergers?’ 2002 Fordham Corporate Law Institute (Hawk ed. 2003) 181; N Hinten-Reed and P.D. Camesasca, 'European merger control: tougher, softer, clearer?' [2003] ECLR 458; V. Verouden et al, 'The Draft EU Notice on Horizontal Mergers' [2004] Antitrust Bulletin 243; J. Vickers, 'How to Reform the EC Merger Test?' in G. Drauz and M. Reynolds (eds), EC Merger Control: A Major Reform in Progress (Oxford: Oxford University Press, 2003).

12 Volvo/Scania [2001] OJ L 143/74.

${ }^{13} \mathrm{M}$. Ivaldi and F. Verboven, 'Quantifying the effects from horizontal mergers in European competition policy' (2005) 23 International Journal of Industrial Organization 669; See P. Christiansen, K. Fountoukakos and D. Sjöblom, 'Mergers' in J. Faull and A. Nikpay (eds), The EC Law of Competition (Oxford: Oxford University Press, $2^{\text {nd }}$ ed, 2007) para. 5.234 for an insider's explanation.
} 
ECMR be redrafted and apply a standard whereby mergers are caught if they would 'substantially lessen competition' as in the merger laws of the US, UK and Australia for example? ${ }^{14}$

The answer given in the EU legislature is a compromise text: the new ECMR provides that a merger would be blocked if 'it would significantly impede effective competition in the common market or in a substantial part of it, in particular as a result of the creation or strengthening of a dominant position. ${ }^{\prime} 5$ This is said to retain some legal certainty by making previous determinations of dominance still relevant while allowing the Commission to regulate mergers whose anticompetitive effects do not stem from the creation of a dominant player in the market. Thus, the Commission now has two routes to demonstrate that a merger resulting in unilateral effects should be blocked: indirectly by establishing the creation or strengthening of a dominant position (allowing an inference that there would be an adverse effect on competition) as was the case under the old ECMR, or directly by establishing that the merger would significantly impede effective competition without proof of dominance.

In this essay I make two central claims. First, against the conventional view that reform was required because the dominance test did not allow the Commission to regulate all anticompetitive mergers, I suggest that the concept of dominance was flexible enough. ${ }^{16}$ The motivation for reform had more to do with the Commission's wish to decouple the affinities that existed between the ECMR and Article 82 so that the two legal provisions could develop independently. Moreover, I show that economists' dissatisfaction with EC merger law was not so much with the legal standard, but with two features of the analytical method used: (i) a narrow focus on market structure which ignores other means of forecasting the effects of mergers; (ii) a failure to test the overall welfare effects of mergers. The second claim is that the Horizontal Merger Guidelines and the application of the new standard require clarification and limitation. The Guidelines merely list a number of factors that the Commission may take into account without offering enough detail as to which factors count in which cases. Below, I suggest that there are four theories of harm that have invited different methods of analysis and when the guidelines are revised attention should be paid to providing a more structured document. This would serve to limit the Commission's discretion, which is necessary in that the first major decision that appears to apply the new standard without reference to the concept of dominance embodies industrial policy considerations.

\footnotetext{
${ }^{14}$ S.35 Enterprise Act 2002 (UK); S.50 Trade Practices Act 1974 (Australia); S. 7 Clayton Act 15 USC 18 (US).

15 Art. 2(3) Council Regulation (EC) No 139/2004 of 20 January 2004, [2004] OJ L24/1. Recital 25 clarifies that the only reason for this is to fill the gap in horizontal merger cases.

16 Along similar lines, A Christiansen "The "more economic approach" in EU merger control - A critical assessment' Deutsche Bank Working Paper Series, Research Notes 21 (1 March 2006) (available at www.dbresearch.com).
} 


\section{THE LIMITATIONS OF THE DOMINANCE STANDARD}

\section{REJECTING THE CONVENTIONAL ANALYSIS}

The essence of the conventional arguments in favour of departing from the dominance test may be summarised as follows. ${ }^{17}$ Lawyers argued that the whole point of dominance is that one firm is bigger than everyone else in the market, so you cannot invent a position of mini-dominance in a setting like the Baby foods case - there Gerber is dominant and no other firm can be given the same label. So this merger between the two smaller competitors could not be regulated under a dominance test, indicating that there is a 'gap' in the standard in the ECMR. This position tallied with the economists' analysis: in their view, dominance was a legal standard that meant monopoly and that this prevented competition authorities from addressing the risks of anticompetitive behaviour in oligopoly markets.

However, both the legal and economic views summarised above are mistaken, because they misunderstand the meaning of dominance in EC competition law. Dominance does not mean monopoly, nor does it require market leadership. This is illustrated by the European Courts' interpretations of this concept: the Courts have found dominance for the purposes of Article 82 and the ECMR with market shares as low as 40 per cent, and have often stated that a degree of competition in the market is not incompatible with dominance. Indeed, decreasing market shares are not evidence that the firm is not dominant - in two key precedents, United Brands and $B A$ /Virgin the Commission found dominance with shrinking market shares, facing a vibrant competitor that the dominant firms were trying to fight off. ${ }^{18}$ Dominance, in other words, means commercial power to resist competitors' entry, it does not mean the power to behave completely independently of rivals. ${ }^{19}$ Moreover, dominance measured in a fairly mechanistic manner: the Commission defines a relevant product and geographical market, identifies the players' market shares and when the joint market shares of the parties reach the $40 \%$ mark, the Commission begins to consider other evidence, normally: the strength of current competitors, likely entry of new ones, and buyer power. If the impression gathered from this evidence is that the merged entity is stronger than its rivals, then there is dominance. Accordingly, a flexible interpretation of the Commission's practice would have allowed it to block the Babyfoods merger and the Volvo/Scania merger in those Member States where the merged entity was not the market leader. In the Babyfoods case for example, a narrower market definition was plausible: Heinz and Beech Nut could be said to be in a different market from Gerber when considering their sales to supermarkets. Supermarkets would always store Gerber, but would then choose to stock the second shelf with either Heinz or Beech Nut. Thus, the two parties to the merger were in competition for that second shelf. In

\footnotetext{
${ }^{17}$ See $\mathrm{n} 11$ above for the key literature.

18 Case 27/76 United Brands v Commission [1978] ECR 207; Case C-95/04P British Airways v Commission judgment of 15 March 2007.

${ }^{19}$ G. Monti, 'The Concept of Dominance in Article 82' (2006) 2 European Competition Journal 31.
} 
that narrow market (the second shelf in supermarkets) the merger is one that creates a single, dominant player. Gerber would have no chance of conquering the second shelf because supermarkets were eager to have two brands, and other baby food manufacturers were insufficiently strong to penetrate that market.

Why then were lawyers supporting a very restrictive interpretation of dominance? One answer has little to do with merger law and more to do with Article 82. The concern that some lawyers had is that if one were to find dominance too easily in merger cases this would spill over into Article 82 and lead to an overly extensive application of that provision. Thus, lawyers wanted a clean break between the ECMR and Article 82, so that these two legal instruments could develop independently of each other. There is some validity to this view if one examines two documents. The first is the 2002 proposal for reforming the ECMR where the Commission thought that the perceived gap in the regulation could be resolved by widening the concept of dominance, by inserting Article 2(2): 'For the purpose of this Regulation, one or more undertakings shall be deemed to be in a dominant position if, with or without coordinating, they hold the economic power to influence appreciably and sustainably the parameters of competition, in particular, prices, production, quality of output, distribution or innovation, or appreciably to foreclose competition. ${ }^{20}$ The intention was first to retain legal certainty established through a decade of successful enforcement of the old test and second to decouple the concept of dominance in Article 82 and that under the ECMR. However, this was too confusing: why should the same word have different legal meanings in competition law? The second document that is helpful in this regard is DG Competition's Discussion Paper on the Application of Article 82 to Exclusionary abuses published in 2005, where there is an interest in narrowing down the concept of dominance only to situations where an undertaking has significant market power. ${ }^{21}$ This project would be seriously undermined had the Commission continued to water down the meaning of dominance in its merger decisions. Accordingly the lawyers' agenda was shaped by the risks of a wide concept of dominance, not by its limitations.

\section{THE MORE SIGNIFICANT DEFECTS OF THE DOMINANCE STANDARD}

However, there are two real problems with the dominance test, but these have not been emphasised enough. The first has to do with developments in economics, the second with the scope of analysis of anticompetitive effects. These two problems explain why economists were concerned with the dominance test.

20 EC Commission Proposal for a Council Regulation on the control of concentrations between undertakings [2003] OJ C20/4, see also para 55 of the explanatory memorandum.

21 The Discussion Paper and related documents can be accessed here: http://ec.europa.eu/comm/ competition/antitrust/art82/index.html. See also T. Eilmnasberger, 'Dominance - the Lost Child? How Effects-Based Rules Could and Should Change Dominance Analysis' (2006) 2 European Competition Journal 15. 


\section{Developing new methods to forecast anticompetitive effects}

Recent economic analysis has been critical of the structural analysis of unilateral effects cases in the US and the EU. That is, both agencies use market shares, entry barriers, and lack of buyer power as proxies that allow them to infer that the merger is anticompetitive. But advances in economics have shown the limitations of a structural approach. For instance, Whinston has queried whether the US merger analysis that hinges on market definition and measuring the change in concentration levels could not be replaced by other economic techniques (suggesting merger simulation, residual demand estimation, and event studies). ${ }^{22}$ Similarly Ivaldi and Verboven propose three alternative techniques to predict the anticompetitive effects of mergers (a hypothetical market power test, an actual market power test, and a comparative market power test) and they distinguish these from the 'traditional market power proxies' that the Commission normally deploys. ${ }^{23}$ And so what arises from the economic literature is an interest in changing the method by which anticompetitive effects are predicted - a wish to shift away from an indirect mechanism of proving anticompetitive effects (based on market definition, measuring the change in concentration, examining buyer power and entry barriers) towards methods that predict the effects of mergers more directly through the use of econometric analysis. It is worth summarising a few of these suggested methods to illustrate that the debate on methods to prove anticompetitive effects is more important than the legal label affixed to the merger test.

The hypothetical market power test is one that lawyers are already familiar with because it underpins market definition and the SSNIP test therein. The test calculates how profitable a price increase by the merged entity would be. Applied to Volvo/Scania Ivaldi and Verboven found that a 5\% price increase by the merged entity would be profitable, while a price increase of $10 \%$ is not profitable in nine countries, but it is more profitable than a $5 \%$ price increase in the other seven countries. Thus, the merger should be blocked at least in those countries where the firms are able to increase price profitably by 5 or $10 \%$. This finding does not depend on what the relevant market is and what the merged entity's market shares are.

Merger simulation is carried out by considering demand and cost functions for the relevant products and using this data to calculate the price that would result given the merger between two firms. This approach requires a correct estimate of demand conditions and a correct understanding of how firms will behave post merger (with the risk that the pre-merger conditions of competition may change post-merger). It ignores the effects on entry and investment that may

\footnotetext{
22 M.D. Whinston, Lectures on Antitrust Economics (Cambridge (MA): MIT Press, 2006) 100.

${ }^{23} \mathrm{M}$. Ivaldi and F. Verboven, 'Quantifying the effects from horizontal mergers in European competition policy' (2005) 23 International Journal of Industrial Organization 669.
} 
result from the merger, ${ }^{24}$ but again it is not premised upon defining markets and adding up the market shares of the merged entity.

A final, most provocative suggestion is the deployment of event studies. This approach is based on the view that a merger that is efficient is bad for rivals and one that creates market power is good for rivals (who can also raise prices). Therefore, one can look at the stock market reactions of rivals after the merger announcement to get an indication of the effects of the merger: if the value of rivals' shares goes up, the merger is anticompetitive because investors foresee that the rivals will be able to make more profits post merger (by increasing prices) but if the value of rivals' shares falls, the merger is not anticompetitive but likely to be efficient. ${ }^{25}$ No competition authority would countenance applying this method in isolation but one significant insight of this approach is that it emphasises that the anticompetitive effects of mergers are not limited to the unilateral price increase of the merged entity. In addition, rivals too may raise prices and contribute to the loss of economic welfare.

These three approaches allow a competition authority to forecast whether the merger is likely to result in higher prices without defining markets and working out market shares. They prescribe a completely different methodology for working out whether a merger is anticompetitive. Thus, one of the real problems with a dominance test is that it risks avoiding the use of more sophisticated and precise economic tools. These observations tally neatly with the approach that was suggested in the draft guidelines on horizontal mergers, issued at a time when the Commission was planning to define dominance more widely under the ECMR than under Article 82. ${ }^{26}$ Here, the Commission distinguished between two sorts of unilateral effects: those that resulted from the creation or strengthening of a 'paramount market position' and those that 'may diminish the degree of competition in an oligopolistic market by eliminating an important competitive constraint on one or more sellers, who consequently would be able to increase their prices. 27 The first category was designed to catch anticompetitive mergers evidenced through high market shares and other structural indicators, the second category included three theories of harm: first where firms compete primarily in output, then a merged entity's knowledge that other competitors are unable to increase output creates an incentive for the merged entity to reduce output; second where products are differentiated and competition is principally price-based, the merger of two firms that produce close substitutes can give the new entity an incentive to raise price knowing few customers will switch to other brands, provided other competitors are unable to reposition their products; third in

24 n 22 above, 100-102.

25 See generally, B.E. Eckbo, 'Horizontal Mergers, Collusion and Stockholder Wealth' (1983) 11 Journal of Financial Economics 241 and R. Stillman, 'Examining antitrust policy towards Horizontal mergers' (1983) 11 Journal of Financial Economics 225.

26 Commission Notice on the appraisal of horizontal merges under the Council Regulation on the control of concentrations between undertakings 11 December 2002 (available at: http://ec.europa.eu/comm/ competition/mergers/review/)

27 ibid para 11. 
bidding markets, anticompetitive effects may occur where the merging firms are the two bidders with the lowest costs. ${ }^{28}$ While the Guidelines were somewhat imprecise in places ${ }^{29}$ they captured the gist of the economic advice.

\section{Effects on the merged entity versus effects on the market}

The second problem with dominance can be understood by referring back to the discussion of event studies: the dominance test merely measures the effect that the merger has for the prices of the merged entity: it does not ask what the overall effects of the merger are, and how rivals to the merged entity may behave. However, it is likely that if a merger gives one firm the power to raise prices, this will affect competitors: if they are unable to increase output to capture more of the market, their incentive will be to raise prices, so the anticompetitive effects caused by the merger are felt by all of the market, not just by that segment served by the merged entity. ${ }^{30}$ An article by two Commission officials (one of them the first Chief Economist at DG Competition) where they review a number of potential cases where the new test in the ECMR might have made a difference is interesting in this regard. Much like the findings of this paper, they reach the conclusion that in none of the horizontal mergers in their sample has the new test made a difference, but that the new test was significant in a vertical merger. ${ }^{31}$ At first blush, the latter is a particularly puzzling conclusion because the debate about the gap in the ECMR had always been conducted in terms of horizontal mergers. What the authors are discussing however is the failure of the dominance test to examine the effects of the merger on the market as a whole. Accordingly they argue that if one were to look only to whether the merger created or strengthened a dominant position this is short sighted and can lead to over or under enforcement. It leads to over enforcement when the merger is overall efficient or when the merged entity is already dominant and acquires a very small rival so that the merger has no tangible effect on competition. It leads to under enforcement because it focuses on the dominant firm and not on the response of competitors, for example it ignores the anticompetitive effects resulting from the competitive fringe firms when they raise prices in response to the price increase of the merged entity. In this scenario, the overall welfare effects are only captured if one looks at the market price as a whole rather than just the price of the merged entity. This article is significant in that even economists embedded within DG Competition saw the debate about the reform in a different light from the way the debate is

\footnotetext{
28 ibid paras 30-39.

29 See in particular the helpful commentary from the American Bar Association (available at: http://ec.europa.eu/comm/competition/mergers/review/).

30 Note that the decision of other firms to raise prices in this context has nothing to do with tacit collusion. The scenario is more akin to that of a market with a monopoly and a competitive fringe, where once the monopoly has set a high price, the competitive fringe (if unable to increase output) will follow the price increase.

${ }^{31}$ L-H Röller and M. de la Mano, 'The Impact of the New Substantive Test in European merger Control' (2006) 2(1) European Competition Journal 9 (the decision is Case M.3696 O.EON/MOL 21 December 2005).
} 
presented conventionally. Moreover, if we follow their suggestion that a competition authority assess the effects of a merger on the market as a whole, this raises a number of different and difficult issues that are not dissimilar from those that affect mergers suspected of having coordinated effects. That is, one would have to find ways of testing how the merger's anticipated performance would affect other market players and estimate their price increases. However, neither the ECMR, nor its guidelines, nor the approach in other jurisdictions devise such an approach.

\section{SUMMARY}

The key lessons that legislators should have taken from the economic literature are two. First, that market definition is not always the only way to begin an analysis of merger cases. Rather, an economically sound merger policy would be one where the agency was able to determine anticompetitive effects indirectly (through defining markets, counting market shares and evaluating entry barriers) and directly (through the use of economic models that serve to predict the welfare effects of a transaction) depending on the circumstances of the case and the available evidence. Both methods tell us that a merger should be banned when the merged entity has enough market power to reduce output and increase price. That we call the standard for review 'dominance' or a 'substantial lessening of competition' is largely irrelevant. Accordingly, reform of the ECMR was not necessary to accommodate these novel insights derived from economics. Nevertheless, the reform of the ECMR perhaps makes it clear that the Commission is committed to using these new methodologies by emphasising that the focus of its analysis is on the anticipated effects of a merger, and not on market structure. The second lesson is the effects of a merger must be judged in the round by considering how competitors might react. However, the Commission never stated explicitly that this was a reason for the reform. And the refusal to take this approach was for good reasons: in an ideal world one would like competition authorities to examine the effects of any market behaviour on the market as a whole, but this is often extremely costly and information is hard to gather. Better to focus on analysing a smaller range of effects that can be measured with relative ease than to opt for an unmanageable standard. 32

In sum, law and economics interacted in a peculiar manner: lawyers wished to decouple merger policy from Article 82, while economists were looking for methodological changes to the analysis of mergers. However, while the two camps started from different premises the reform seems to satisfy both: lawyers achieved

32 In a similar vein, see D. Carlton, 'Does Antitrust Need to be Modernized?' (January 2007) Economic Analysis Group Discussion Paper No. 07-3 Available at SSRN: http://ssrn.com/ abstract $=956930$, noting that a consumer welfare standard, while less precise than a total welfare standard, is more manageable. 
the decoupling they wished for, and economists see a test that allows the Commission to deploy all relevant economic thinking to examine mergers.

\section{THE IMPACT OF THE NEW TEST}

\section{GENERAL OBSERVATIONS}

There are two difficulties in trying to explain what impact the new test has had to date: counting the cases that would not have been regulated under the old dominance test, and presenting a precise indication of which factors are relevant in which cases.

In terms of counting the cases, one has to decide what the significance of the reform is. If, as I argued above the reform is about reflecting an evolution in the economic analysis of horizontal mergers that shifts away from a structural approach to examining the effects of a merger directly, then as shown below especially with the cases discussed in the next sub-section, the Commission had already begun to deploy some of the new analytical methods summarised above before the reform of the ECMR. ${ }^{33}$ And there are a number of other decisions where the structural approach was applied to test for dominance but these findings were supplemented by more direct methodologies. ${ }^{34}$ This approach seems to have continued under the new ECMR: rather than carrying out either a dominance test based on structural factors or a test for unilateral effects absent structural factors indicating dominance, the Commission runs the two tests in parallel. ${ }^{35}$ A study of the 19 phase II decisions by the Commission that have been decided under the new ECMR and have been published at the time of writing, ${ }^{36}$ shows that the Commission, under headings entitled 'non-coordinated effects', deploys an analysis that follows in a fairly mechanical manner the steps articulated in the Guidelines on Horizontal Mergers which incorporate both structural and other factors more closely linked to the new economic methods discussed above.

\footnotetext{
${ }^{33}$ In a similar vein, J. Boyce, D. Loukas and A. Tubbs, 'Merger Control' in Roth and Rose (eds), Bellamy \& Child European Community Law of Competition (Oxford: Oxford University Press, 2007) footnote 603.

${ }^{34}$ In addition to the examples discussed in this section, see: Case M.2861 Siemens/Dragerwerk [2003] OJ L291/1 (dominance plus parties are each other's closest competitors); Case M.3216 Oracle/PeopleSoft [2005] OJ L218/6 paras 187-205 (inconclusive market shares but bidding studies showed remaining competitor would prevent price increases by the merged entity); Case M.3544 Bayer Healthcare/ Roche (OTC Business) (19 November 2004) (high market shares in Austria but consumer preferences showed goods were not close substitutes); Case M.2817 Barilla/BPS/Kamps (25 June 2002) (narrow market definition to prove dominance plus reference to closeness of competition between the two firms); Case M.3083 GE/Instrumentarium [2004] OJ L109/1, Case M.2256 Philips/Agilent (2 march 2001), and Case M.2537 Philips/Marconi Medical Systems (17 October 2001) (use of quantitative evidence to test closeness of competitors).

35 n 33 above, para. 8.208.

3628 March 2008. Seven more decisions reached by this date were only publicised by press release, with insufficient information for analysis.
} 
The word 'dominance' is often absent from the decisions, save in instances where the market shares are very high, ${ }^{37}$ but we cannot conclude that the new test has had an impact in all cases where the word 'dominance' is absent. This makes it impossible to identify those decisions that would have been scrutinised under the old structural test, and those that are only reviewed because the new methods allow the Commission to discover anticompetitive effects that it could not forecast with the dominance test.

Instead, if one agrees with the conventional rationale for the reform, that the dominance test created a real gap, then one way of counting the 'gap cases' is to rely on the Commission's official documents. These reveal only two (Linde/BOC and T-Mobile Austria/tele.ring). ${ }^{38}$ The rationale given by the Commission for identifying these is that in both the merger created competitive concerns even though the merged entity would not have been the market leader. However this misconceives the potential breadth of the new test if one agrees that there was a gap in the old ECMR. Market leadership was never a sufficient element under the dominance standard, only a significant level of leadership triggered the old test. In Novartis/Hexal, (a post-reform decision) for instance, after finding that the merged entity in one relevant medicine market would have been the 'market leader' with a market share of between 30-40 per cent, it continued in this way: '[d] espite the relatively limited combined market share the market investigation has revealed serious concerns in this market related to possible unilateral effects created by the merger.' ${ }^{39}$ This was because the merger brought together two products which a substantial number of customers saw as their first and second choice. This too can be classified as a 'gap' case because the Commission did not state that the merger created or strengthened dominance, merely that the parties would have an incentive to increase prices post merger unchecked by other competitors, customers or consumers. It follows that the potential breadth of the new standard is greater than that reported..$^{40}$

To a certain extent, the inability to identify those decisions where the new test has made a difference is to be welcomed because as was argued in section 2, the real question in horizontal merger cases where unilateral effects are suspected is whether the merger will cause prices to rise, and proof that the merger creates a dominant position is but one method of showing this effect. This point is recognised implicitly in one of the post-2004 merger decisions (Kronospan/Constantia), where the Commission refers to its calculation of market shares as a 'first proxy to assess competitive effects.' ${ }^{11}$ Having shown that the merger would have created a player with $60-80$ per cent of a market where no

37 E.g. Case M.4187 Metso/Aker Kvaerner (12 December 2006) para 78; Case M.4000 Inco/Falconbridge (4 July 2006); Case M.3796 Omya/ Huber PCC (19 July 2006).

38 Report on Competition Policy 2006 para 16. Earlier annual reports and issues of the Competition Policy Newsletter published in 2007 do not discuss other cases.

${ }^{39}$ Case M.3751 Novartis/Hexal 27 May 2005, 10.

40 On this basis, Case M.3687 Johnson \& Jonson/Guidant (25 August 2005) and Case M.3998 Axalto/Gemplus 19 May 2006 (below) would also be gap cases.

${ }^{41}$ Case M.4525 Kronospan/Constantia (19 September 2007) paragraph 44. 
other competitor had a market share greater than 10 per cent, the Commission continued by verifying whether other market indicators suggested that the merger would substantially impede effective competition (ability of customers to find alternative supplies, likelihood of competitors to increase output if there is a price rise, whether the transaction eliminates an important competitive force, and entry barriers). This qualifies the conventional understanding of the role of market share proxies under the dominance test repeated in GE $v$ Commission: 'very large shares are in themselves, and save in exceptional circumstances, evidence of the existence of a dominant position. ${ }^{3} 2$ Now the Commission tests for the presence of countervailing factors when faced with high market shares in all cases, not just exceptionally. ${ }^{43}$ And even when market shares are below the conventional dominance thresholds, the Commission tends to verify whether other factors may indicate risk of competitive harm. ${ }^{44}$

Thus a structural approach is replaced by a multi factor approach, and in determining what other factors are relevant, the Commission is faithful to the list in the guidelines: market shares, closeness of competition, possibilities of switching, ability of competitors to increase supply, ability of the merged entity to make it more difficult for competitors to expand, whether the merger eliminates an important competitive force. ${ }^{45}$ However, there is as yet little guidance on which factors are relevant in which cases, and on the weight given to different factors. ${ }^{46}$ As a result it may help to consult the US Horizontal Merger Guidelines which distinguish between two types of unilateral effects: those that arise when markets are made up of firms selling differentiated products and those arising when firms sell homogeneous goods. (These correspond broadly to the Bertand and Cournot models of competition. $)^{47}$ We find the same two categories in the EC Guidelines, ${ }^{48}$ but here they are not listed as alternatives. It would have been preferable if the Commission guidelines had followed the approach of the US because this would help show that two distinct sets of factual and economic inquiries can be undertaken. In addition, the European guidelines add two further factors that weigh against mergers in a significant way: where the merged entity is likely to

\footnotetext{
${ }^{42}$ Case T-210/01 General Electric v Commission [2005] ECR II-5527 paragraph 115 (emphasis added).

${ }^{43}$ Horizontal Merger Guidelines [2004] OJ C31/5, paragraph 41, where the passage cited from the GE judgment is cited but reinterpreted in the way suggested here.

${ }^{44}$ E.g. in Case M.4404 Universal/ BMG Music Publishing (22 May 2007) a 'leading position' in the market for mechanical and performance rights, with market shares around 30\% was not of concern having found buyer power (paras 187-190); the merger would have created a leading player in the on-line performance rights market, but it seems that here a dominance test would have been equally applicable.

${ }^{45} \mathrm{n} 43$ above, paras 27-38.

${ }^{46}$ A particularly striking example is Case M.3465 Syngenta CP/Advanta (17 August 2004) para.49 where the Commission concludes that the merger created a dominant position in some geographical markets or led to non-coordinated effects in a highly concentrated oligopolistic market in other geographical markets without any meaningful examination of the differences (though this is a phase 1 decision so less detail is provided).

47 Department of Justice and Federal trade Commission Horizontal Merger Guidelines 1992 (revised 1997) Sections 2.2.1 and 2.2.2.

48 n 43 above, paragraphs 28-30 for differentiated products and paragraphs 32-35 for competition based on quantity.
} 
behave in an exclusionary manner, ${ }^{49}$ and where the target of the merger is an important competitive force. ${ }^{50}$ We use these four categories below to illustrate that while the Commission's current analytical stance should be broadly welcomed, a more systematic presentation in the guidelines would increase certainty and constrain the Commission's discretion.

\section{DIFFERENTIATED PRODUCTS}

This is by far the largest category of cases where the application of the dominance standard (if narrowly interpreted so that dominance is equated with nearmonopoly) might have led to the Commission failing to regulate an anticompetitive merger. Here, a merger may lead to anticompetitive effects if the firms proposing the merger produce goods that are each other's closest substitute. If they do, then the Commission takes the view that the market shares may underestimate the likely effects of the merger, and that in reality the merger creates a dominant position regardless of the market shares. Conversely, if the parties' goods are not each other's closest competitors then this is evidence that the market shares over estimate the effects of the merger, so that there is no competitive risk. We can distinguish between two types of methods that are used to examine if the acquiring firm and the target are each others' closest competitors: the first is bidding studies and second is composed of tests how consumers view the various products in the market. A few examples will suffice to indicate the gist of these methodologies.

Bidding studies were used in Axalto/Gemplus, a horizontal merger in the market for smart cards. ${ }^{51}$ The combined market share in the market for payment card would have been [30-40\%] and in that for SIM cards [40-50\%]. On a dominance standard, these appear close but perhaps insufficient to give rise to a risk of unilateral effects, but the Commission then cross-checked by looking at consumer demand through bidding studies: in the market of payment cards, the studies revealed that the two parties were the successful bidder and the second bidder only in [15-25\%] of the bids, and only [25-35\%] of clients are common customers of the two parties. In SIM cards the two were the winning companies and second bidder in [10-20\%], and there were credible and close substitutes from competitors. Accordingly the market shares overstated the competitive risk posed by the merger.

Consumer perspectives in branded goods were considered in Bayer/Roche: the parties sold anti-acid over the counter medicines: Bayer had the Talcid brand and Roche the Rennie brand. In Austria the combined market share would have been 55-60 per cent but the evidence of consumer opinion suggested that this market share overstated the market power the parties had. Rennie was positioned at the

\footnotetext{
49 ibid paragraph 36.

50 ibid paragraphs 37-38.

51 n 40 above.
} 
more casual end of the market, Talcid was a more distant substitute. Rennie was seen as a simple drug marketed through mass advertising, while Talcid was marketed through pharmacists' endorsements. This approach is not dissimilar to that taken by the UK Competition Commission (CC) in a recent ruling allowing a merger in the market for football pools. While the merged entity would have $99 \%$ of the market share in this particular betting product, the CC found that the two games were not in competition with each other, that consumers of one did not see the other as a substitute. The CC declined to go beyond saying that the evidence showed either that the two firms, Vernons and Littlewoods, were operating on separate markets or that the two were in the same market and did not exercise a competitive constraint on each other. ${ }^{52}$ This is to be welcomed and reflects the position taken in this paper: market definition is a helpful device in many competition law issues, but in markets where products are differentiated, market definition is not as helpful, and ultimately the key question for a competition authority is whether the merger gives the entity market power. In the examples summarised here, no market power concerns arose in spite of the appearance created by high market shares.

\section{HOMOGENEOUS PRODUCTS}

In this setting the US Guidelines suggest that a merger of two firms whose combined market share is $35 \%$ or more would find it profitable to reduce output because it would have a large base of sales on which it can make profits, but a unilateral price increase would only be likely if the merged entity's competitors are unable to increase output by a sufficient amount to make the price rise unprofitable, because they have capacity constraints. ${ }^{53}$ This kind of unilateral effect was present in the Georgia-Pacific/Fort James merger of the two largest producers of 'away-from-home' tissues (e.g. paper napkins and toilet tissues used in offices). Their joint capacity would have been $36 \%$ and all operators were working at full capacity, with little scope for expansion and inelastic demand. In these circumstances the Department of Justice took the view that the merged entity would have had an incentive to 'act as a dominant firm (sic) by restricting production'. 54

A similar finding was reached by the Commission in Linde/BOC in the helium wholesale market. Measured by future capacity, the market shares of the players were forecast to be as follows: 55

\footnotetext{
52 Sportech plc and the Vernons football pools business of Ladbrokes plc (11 October 2007), summary, para.8 (available at http://www.competition-commission.org.uk).

53 US Guidelines n 47 above paragraph 2.22.

${ }^{54}$ Commentary on the Horizontal Merger Guidelines (2006) (available at: http://www.usdoj.gov/atr/ index.html).

${ }_{55}$ Case COMP/M.4141 Linde/ BOC (6 June 2006) paragraph 159.
} 


\begin{tabular}{|c|c|c|c|c|}
\hline Linde & BOC & $\begin{array}{c}\text { Air } \\
\text { Products }\end{array}$ & Praxair & $\begin{array}{c}\text { Air } \\
\text { Liquide }\end{array}$ \\
\hline$[0-10] \%$ & {$[20-30] \%$} & {$[20-30] \%$} & {$[20-30] \%$} & {$[10-20] \%$} \\
\hline
\end{tabular}

The Commission's concern was that in the years before the merger Linde had been a keen competitor, and that post-merger this incentive to grow its market share would be dented. Two rationales were deployed to explain this: first that pre-merger Linde would have wished to 'invest' by setting lower prices so as to gain market share, but post merger that investment was less likely because a price decrease over a considerably larger number of units sold is less profitable; second post merger the entity would be able to reduce output and this would be profitable because of high entry barriers caused by capacity constraints in that there are very few natural gas fields from which helium can be made. ${ }^{56}$ One further aspect should have been considered by the Commission (its omission is probably explained by the fact that this is a Phase 1 case where the analysis is not set out completely): this is the ability of the other firms in the market to increase their output should the merged entity choose to reduce its production. This factor is essential because no unilateral effects are plausible if the reduced output does not lead to a price rise caused by a shortage. (For completeness it should be mentioned that the Commission also expressed concerns that the market was prone to co-ordinated effects given the degree of concentration, product homogeneity, transparency to allow for retaliation, and the fact that the merger removed a 'maverick' firm that had been aggressive in the market, suggesting that the merger would cause a price alignment. ${ }^{57}$ )

It is not clear why the 'dominance' test in the ECMR would have made the Commission unable to catch these types of merger - the evidence in both suggests that the merged entity is able to reduce output independently of rivals' actions, so that the standard definition of dominance developed in the case law (the ability to behave independently of competitors, customers and consumers) seems to apply here. ${ }^{58}$

\section{EXCLUSIONARY TACTICS BY MERGED ENTITY}

In the past the Commission has applied the 'dominance' test in scenarios where in addition to the merger creating or strengthening a dominant position, the Commission feared further consolidation of dominance in that the merged entity would be likely to engage in exclusionary practices post merger. ${ }^{59}$ In the context of mergers leading to dominance, this kind of finding must now be read in the light of the Tetra Laval judgment where the Court indicated that when

56 ibid, paras 160-179

57 ibid, paras 180-192.

58 Case 85/76 Hoffmann-La Roche v Commission [1979] ECR 461, para 38-39.

59 G. Monti, EC Competition Law (Cambridge: Cambridge University Press, 2007) 253-5. 
anticompetitive effects materialise through the abuse of a dominant position, the Commission must test whether the likely finding of an abuse of dominance might deter the merged entity from engaging in these exclusionary practices. ${ }^{60}$ However, this control device is inapplicable in cases where the merged entity is not classified as dominant but is able to utilise its increased market power to harm rivals.

Such an approach was taken in Axalto/Gemplus. ${ }^{61}$ As we saw above, the merged entity did not raise concerns about unilateral price increases because the parties were not each other's closest competitors. However the Commission was concerned that post merger they would be the firm with the largest patent portfolio and would be able to utilise this to harm their competitors in the market for smart cards. Before the merger a third party would ask either Axalto or Gemplus for a licence to a given patent but post merger Axalto and Gemplus would no longer compete to license their patents. The Commission thought that the firms would be eager to license their patent not only because of the fees but because this would spread its technology. In contrast post-merger the Commission feared that the merged entity would reverse engineer rival's products and threaten them with lawsuits if they suspected one of the thousands of patents held by the merged entity had been infringed. However, in this instance the relevant market is that of the IP rights necessary to operate successfully in the downstream market for smart cards, so arguably the merger is one that creates a dominant position in the patents market, which the parties can use as a means of gaining greater market power downstream. (Indeed towards the end of the analysis the Commission refers to the creation of a dominant position in the SIM card market, although this statement seems unsupported by the preceding assessment). Again, this is a case that falls within the old 'dominance' test even if the Commission is reluctant to frame the decision with that term, so this category of cases could potentially see expansion to instances where a merged entity is unable to reduce output or increase price but the Commission fears it is able to exclude rivals.

\section{ELIMINATION OF AN IMPORTANT COMPETITIVE FORCE}

That the merger eliminates a pesky competitor is often associated with coordinated effects, but now finds its way in unilateral effects too; the Linde/BOC merger considered above is an example of this, although when looking at unilateral effects the Commission's focus was mainly on the ability of the merged entity to reduce supply. The acquisition of the maverick firm merely confirmed the ability to raise prices and was not a stand alone ground for fearing anticompetitive effects. In T-Mobile Austria/Telering instead, the Commission devised a novel theory, considering that a merger in a differentiated product market that eliminates the most important competitive force is anticompetitive even if no dominant firm results, and even if there is no tacit collusion (although in a belt-and-braces

${ }^{60}$ Case C-12/03 P Commission v Tetra Laval judgment 15 February 2005.

61 n 40 above. 
approach the Commission does examine the risk of co-ordinated effects as well). ${ }^{62}$ The competition concerns occurred in the market for mobile telecommunications services, where the market shares in 2005 , measured by customers were as follows:

\begin{tabular}{|l|c|c|c|c|}
\hline $\begin{array}{c}\text { T- } \\
\text { Mobile }\end{array}$ & Tele.ring & Mobilkom & ONE & H3G \\
\hline$[20-30 \%]$ & {$[10-20 \%]$} & {$[35-45 \%]$} & {$[15-25 \%]$} & {$[<5 \%]$} \\
\hline
\end{tabular}

The merged entity would not become dominant, but the Commission noted several features which suggested that unilateral effects would occur. First, that Tele.ring had almost doubled its market share in the last three years, while Mobilkom and T-Mobile have lost market shares in that period. Second, ONE was developing a different commercial strategy, selling higher value services and H3G faced an uncertain future given the regulatory framework. Third, Tele.ring was the main reason why Mobilkom and T-Mobile were cutting prices, and its elimination as a market player would reduce the incentive on the two larger firms to reduce prices. Significantly, the Commission did not say that post merger prices would rise, merely that they would not fall as fast as before the merger:

Even if prices do not rise in the short term, the weakening of competitive pressure as a result of tele.ring's elimination from the market makes it unlikely that prices will continue to fall significantly as in the past. ${ }^{63}$

In spite of this risk, the Commission cleared the merger subject to commitments that facilitated H3G's expansion in the near future, in the expectation that it would become the new maverick player in the Austrian market.

The decision seems to use the acquired firm's disruptive presence on the market as they key indicator of anticompetitive harm, ${ }^{64}$ but it is unclear what combination of factors in addition to it will lead the Commission to reach the same conclusion, nor what sort of evidence suffices to describe a target firm as a maverick. ${ }^{65}$ Moreover, while ONE had deployed a different commercial strategy pre-merger, the Commission should probably have considered more fully that firm's ability to reposition itself to become a direct competitor of the merged entity. ${ }^{66}$ There are two further worrying aspects of the decision: first, given the passage quoted above it is not clear why the merger should substantially impede effective competition given that prices would have continued to fall; second the remedy prescribed suggests that the problems in the mobile telecommunications

62 Case M.3916 T.Mobile Austria/ tele.ring 26 April 2006.

63 ibid, para 125.

64 A similar theory of harm was explored in Case M.4523 Travelport/Worldspan (21 August 2007) paras 106-128 but found that the target was not a maverick because (i) target was not charging lower prices (ii) target had been losing market share; (iii) the target and acquirer were not each other's closest competitors. $65 \mathrm{~J}$. Killick and A. Schulz 'Horizontal and Vertical mergers' in Amato and Ehlermann n 5 above, 467.

${ }_{66}$ This is in fact noted in $\mathrm{n} 43$ above, para 30. 
market in Austria had more to do with a defective regulatory regime than with the merger, so the Commission stepped in to regulate a market, not to prevent anticompetitive harm. In sum, this first decision where the Commission felt the dominance test would have prevented the application of the ECMR is one where the Commission appears to stretch its powers significantly.

\section{CONCLUSIONS}

In the debate over the reform of the ECMR, economists worked with lawyers but their interaction was akin to two ships that pass in the night: they only understood each other's concerns partially. Economists thought that dominance meant monopoly, and felt that this test was too narrow because it did not allow the application of merger laws against firms in oligopoly markets, moreover they thought that focusing on dominance did not give a full picture of the anticompetitive effects resulting from a merger. Lawyers however had already been using the more recent economic standards to test the effects of mergers before the reform of the ECMR and they had little interest in reforming merger law to assess the market-wide effects of mergers. Instead, lawyers were more interested in avoiding spill over effects from the merger law into Article 82 than in designing legal standards that would accommodate new economic insights. In the end however, the reform satisfied both camps: economists because the new test focuses on the welfare effects of the merger, lawyers because the dominance standard is retained (important for legal certainty so that the previous case law is still applicable) and because the new test allows them to avoid further widening the scope or the legal meaning of dominance. Accordingly my claim that reform was unnecessary is irrelevant since the new test can work well enough to address the economic issues, but holds a lessons for subsequent reforms: deeper understanding between lawyers and economists is required so that both are debating the same issues.

When we turn to the application of the new standard and the Guidelines, the willingness of the Commission to explore wider factors to gauge the effects of mergers is to be welcomed but a more structured set of guidelines is required to explain the various theories of harm that the Commission is pursuing. The sole reported decision to date that is recognised by the Commission as being one that the new test enabled them to take and that would not have been reviewed under the dominance standard is very worrying - not only is it not clear what factors are essential to intervene, but the whole decision appears 'regulatory' in nature shaping the market to maximise competition. These criticisms suggest that a possible side effect (or perhaps an intended effect?) of the reform is that the Commission has greater discretion to use merger control as an industrial policy tool. The industrial policy explanation sounds plausible if we refer to the debates in Australia over its choice to reform the substantive test (Australia began with a 
'substantial lessening of competition' test, switched to 'dominance' and then switched back to substantial lessening of competition). Speaking against the second reform, many industrial policy advocates suggested that a more intrusive merger policy would hamper the growth of national industry and thus harm the Australian economy. ${ }^{67}$ In the EC however the Commission's view seems to be that it is able to work a benevolent industrial policy that contributes to the creation of a better European economy.

Another reflection is warranted, and this relates to the implications that the reform has for Article 82. The conventional wisdom is that merger control applies to lower levels of market power than the dominance test, and this is the rationale for abandoning dominance in merger cases. As I have insisted above, this is erroneous: unilateral effects are a manifestation of significant market power, and if a firm is able to raise prices profitably and act independently of rivals, the fact that it is not 'dominant' when its size is measured in market shares is irrelevant. Accordingly in my view every merger that is found to substantially impede competition would, if assessed ex post, be an assessment of a dominant firm and Article 82 applies. Remember that under Article 82 dominance is the ability to behave to a large extent independently of competitors, consumers and customers. ${ }^{68}$ This is exactly the conclusion one reaches when one finds that a merged entity would cause anticompetitive unilateral effects. But, by abandoning the need to talk of dominance in merger cases, this leaves open the space for the Commission to redefine the concept of dominance in Article 82 as a jurisdictional threshold to determine when that provision should apply, or it allows the Commission to establish a safe harbour market share below which dominance is found not to exist. This could allow the Commission to narrow down the scope of Article 82, which is often applied too aggressively. The rationale for a wider net under the ECMR is that merger law is a prudential tool to prevent harmful consequences, and that many mergers fail and are arguably bad for the economy, ${ }^{69}$ so a stricter application of merger rules appears justified. Moreover, merger control is concerned with preventing price increases by the merged entity, and possible follow on increases across the market, while abuse of dominance provisions are focused on exclusionary abuses, which suggests two different notions of market power are needed for the two provisions to work well.

A final reflection is about the role of market definition in competition cases. While it is now de rigueur to begin a competition inquiry by defining markets, the experience under the ECMR confirms that market definition is part of an indirect way of proving the presence of market power and other means exist. The structural approach has attraction because authorities have years of experience in using market definitions and market shares as proxies. Instead the methodologies

${ }^{67}$ J. Clarke, 'The Dawson Report and Merger Regulation' (2003) 8 Deakin Law Review 245, 251-260.

68 n 19 above.

${ }^{69} \mathrm{H}$. Schenk, 'Mergers and concentration policy' in P. Bianchi and S. Labory, International Handbook on Industrial Polcy (Cheltenham: Edward Elgar, 2006) recommending even tougher merger scrutiny as a result of the macroeconomic risks of merger failures. 
suggested above, which shun market definition in favour of direct evidence of market power, are less well established. This means that proof of market power indirectly is administratively cheaper but prone to error, while direct proof of market power is probably administratively more expensive but potentially more precise. Accordingly choosing the best approach to study the potential effect of mergers depends on several variables: the cost of applying a given method, the risk of error, the risk that the authority abuses its discretion and misuses merger policy. ${ }^{70}$ Comparing direct and indirect methods, the dominance test is probably cheaper as parties have experience in operating the various tests, it is less prone to abuse given that the case law has circumscribed the authorities' discretion, but it is likely to be under or over inclusive. Instead, the direct methods are more likely to yield the correct result but more expensive to operate (because of inexperience by the regulators) and more open to misuse. From this perspective, the merits of choosing to use more economics-intensive standards for review can be questioned.

${ }^{70} \mathrm{I}$ draw on the excellent analysis by A. Christiansen $\mathrm{n} 16$ above, and see also the approach I have taken in $\mathrm{n} 59$ above. 